\section{Requests for 'A Hundred Years Ago'}

Sir: It is just over 10 years since the $A$ Hundred Years Ago column was started in the British Journal of Psychiatry. From the outset I have received requests for reprints which, of course, are not supplied to me by the management. The requests, therefore, have had to be ignored and confined to the WPB.

However, it was my impression that the requests had increased in number in recent years, and I thought it might be a useful exercise to collect them and subject them to a somewhat crude analysis. This could give feedback as to the popularity of the column and also, coincidentally, give some idea of the geographical spread of our readership. I, personally, was surprised by the sheer number of requests and, perhaps more importantly, by the 'Heineken Effect', i.e., the fact the Journal appears to reach parts of the globe that other comparable journals fail to reach.

Here, then, is my analysis of 95 requests received for the years 1990-1994 inclusive which I hope will be of some interest to you.

$\begin{array}{lr}\text { USA } & 36 \\ \text { Canada } & 10 \\ \text { Spain } & 8 \\ \text { Germany } & 7 \\ \text { Czechoslovakia } & 6 \\ \text { France } & 5 \\ \text { Israel } & 4 \\ \text { UK } & 3 \\ \text { Belgium } & 2 \\ \text { Italy } & 2 \\ \text { Cuba } & 2 \\ \text { Austria } & 1 \\ \text { USSR } & 1 \\ \text { Switzerland } & 1 \\ \text { Mexico } & 1 \\ \text { Lithuania } & 1 \\ \text { Brazil } & 1 \\ \text { South Africa } & 1 \\ \text { Hungary } & 1 \\ \text { Colombia } & 1 \\ \text { Romania } & 1 \\ \text { Total } & 95\end{array}$

HENRY R. Rolun, Emeritus Consultant Psychiatrist, Horton Hospotal, Epsom. Surrey

\title{
In the nick of what?
}

The guest of honour at the party was a distinguished continental professor of forensic psychiatry whose command of English was more than adequate. The rest of us - the men that is-were in the same line of business and inevitably we talked shop.

The conversation took a random course, but it so happended that at one point one of us expounded on the use of the vernacular in the criminal subculture. He gave as an example the work "nick" used either as a verb or noun. The cognoscenti, he went on, could effect a marvellous economy of language and yet describe very adequately a complicated ongoing criminological process.

He illustrated what he meant. Thieves, venturing forth on a predatory excursion, "went nicking". If caught in the act and apprehended by the police they were "nicked". They were tried or "nicked" by the judge and, if found guilty of the crime, sentenced to a period in the "nick".

We awaited the dawn of enlightenment on the face of the professor, but none came. The embarrassed pause was filled in by a sip of his drink. So fortified he asked very tentatively: "Are the felons then called "knickers'?" "No", came the answer; but it seemed pointless to attempt to explain why not. The pitfalls in standard English are, needless to say, as nought compared with those in the vernacular.

HENRY R. RoLuN, Emeritus Consultant Psychiatrist, Horton Hospital, Epsom 